\title{
The early growth of start-ups: innovation matters. Evidence from Italy
}

Raffaele Fiorentino

Department of Business and Economics, University of Naples Parthenope, Napoli, Italy

Sergio Longobardi

Department of Business and Quantitative Studies, University of Naples Parthenope, Napoli, Italy, and

Alessandro Scaletti

Department of Business and Economics, University of Naples Parthenope, Napoli, Italy

\begin{abstract}
Purpose - Despite the relevance of innovation in entrepreneurship literature, empirical research on the innovation-performance relationship in start-ups is underdeveloped and shows controversial results. To bridge this gap, the aim of this paper is to investigate the role of innovativeness on new venture performance in the early stage of the life cycle.

Design/methodology/approach - Regression modelling and propensity score matching are used to reveal systematic differences in growth between innovative start-ups (ISUPs) and non-innovative start-ups. We use an ad hoc dataset obtained through merging the financial database AIDA with data from administrative sources (Italian Chambers of Commerce and the Italian Ministry for Economic Development).

Findings - The results show that differences in growth can be explained by the different levels of innovativeness in new ventures. Moreover, unlike in prior studies, the innovation inputs matter more than innovation outputs. Indeed, the results support the idea that innovation policies can contribute to maximising the potential of start-ups.

Practical implications - The findings provide suggestions for policy makers and entrepreneurs to help firms configure ex ante appropriate actions to support the growth of new ventures in the start-up stage.

Originality/value - This study is the first to use the new objective measure of start-up innovation, available from the Italian LD 221 register. Second, different types of innovation are investigated as antecedents of firm growth. Third, we employ propensity score matching, which favours revealing systematic differences in growth between ISUPs and non-innovative start-ups. Fourth, the results of our study are the first to offer evidence on the effectiveness of the new Italian sustaining ISUPs policy.
\end{abstract}

Keywords Performance, Growth, Small to medium-sized enterprises, Technological innovation, Propensity score matching

Paper type Research paper

\section{Introduction}

Studies are increasingly answering questions about the innovation process (e.g., Perez et al., 2019), the success factors of innovation (e.g., Dewangan and Godse, 2014), innovation ecosystems (e.g., Oh et al., 2016) or how to measure innovation (e.g., Dziallas and Blind, 2019). However, despite the existing research, policy makers, managers and scholars still need further clarification on the role of innovativeness and its importance as a driver of

(C) Raffaele Fiorentino, Sergio Longobardi and Alessandro Scaletti. Published by Emerald Publishing Limited. This article is published under the Creative Commons Attribution (CC BY 4.0) licence. Anyone may reproduce, distribute, translate and create derivative works of this article (for both commercial and non-commercial purposes), subject to full attribution to the original publication and authors. The full terms of this licence may be seen at http://creativecommons.org/licences/by/4.0/legalcode.
Received 27 September 2019 Revised 29 April 2020 3 July 2020

Accepted 26 August 2020 
EJIM

24,5

performance in terms of competitiveness and profitability, among other factors (Dosi et al., 1995; Porter, 1998; Senge and Carstedt, 2001; Cozza et al., 2012; Santi and Santoleri, 2017).

Theoretical considerations on the link between innovativeness and firm performance suggest that innovativeness might have either a positive or a negative effect on firm growth (Hyytinen et al., 2015). Several scholars have analysed the so-called Gibrat's law framework, from which perspective they hypothesize that firm size follows a random path, and firm growth is influenced by idiosyncratic shocks. Hence, innovation is a process that occurs randomly among firms (Geroski et al., 1993; Dosi et al., 1995). Obviously, this assumption is not confirmed in the economics of innovation literature, where, on the contrary, innovation is considered a strategic and crucial tool that plays an important role in firm growth. Consequently, the decision to invest financial and human resources in innovation is driven exclusively by cost opportunity and market conditions. In particular, “. . .innovation is mainly pursued by new entrants in order to gain new market shares for surviving longer and growing faster than competitors" (Cozza et al., 2012).

Additionally, empirical studies investigating the innovation-growth relationship frequently present mixed findings (Rosenbuch et al., 2011). In the empirical literature, some studies suggest that there is a positive association between the innovativeness of firms and their subsequent performance (e.g., Audretsch, 1995; Cefis and Marsili, 2006; Colombelli et al., 2016; Helmers and Rogers, 2010). However, other empirical studies report that innovation does not affect performance (e.g., Birley and Westhead, 1990; Heunks, 1998), or they find negative performance implications of innovation (e.g., McGee et al., 1995; Vermeulen et al., 2005). Reviews of the innovation-performance research describe the evidence as "mixed", "inconclusive", and "contradictory" (Li and Atuahene-Gima, 2001, p. 1123).

Nevertheless, there are empirical studies suggesting that these results may be context dependent and are not always applicable to younger firms (Boyer and Blazy, 2014; Cader and Leatherman, 2011; Reid and Smith, 2000). The innovation issue is relevant for start-ups, which are traditionally small and medium-sized firms (SMEs) in the early stage of their life cycle. Regardless of their features and dimensions, start-ups play an important role in economic and technological development (Audretsch et al., 2011; Gilbert et al., 2006; Link and Bozeman, 1991; Shepherd and Wiklund, 2009). For resource-scarce new small ventures, the resources required by innovation projects can overstrain their capacity (Acs and Audretsch, 1988; Nooteboom, 1994; Vossen, 1998). New ventures can introduce novel products and processes by internationalisation strategies oriented to new markets, building on previously established networks (Thurner et al., 2015). Additionally, innovation implies increased uncertainty and risks (Eisenhardt and Martin, 2000; Knight, 1921). For smaller entities, the failure of an innovative product evokes existential risks (Nohria and Gulati, 1996). Smaller and, especially, newer firms often lack the organisational capabilities needed for innovation and thus experience a continuing risk of engaging in managerial undertakings without experience. Indeed, the smallness of the analysed organisations promises that relationships between innovation and performance are more immediate and less confounded by other factors. Although economic theory highlights the crucial role of innovation in growth of firm sales (see for example Geroski, 1999), little attention is paid to the influence of innovativeness on the growth of start-ups, and most studies show ambiguous results. Previous studies (Geroski et al., 1993; Geroski et al., 1997) have found a positive, although modest, influence of innovations on growth in the short run, but, at the same time, these scholars have highlighted that innovation exerts an indirect effect on innovative firms' performance by reducing their sensitiveness to adverse macroeconomic shocks. These findings lead to the supposition that innovative firms have internal competencies and behavioural patterns that allow them to weather economic shock and market challenges (Cefis and Ciccarelli, 2005). Contrasting results can be related to contextual factors and subjective definitions of innovativeness. There is a need for quantitative studies based on objective definitions of innovativeness and growth 
measures of performance, where growth can be defined in terms of revenue generation, value addition and expansion in terms of volume of the business (Gupta et al., 2013). Therefore, our research specifically focuses on start-ups in the early stages of their life cycle, and we posit the following research question: Does innovativeness affect the growth of start-ups?

To answer this question, we have collected data from Italian ISUPs (following the implementation of a new Italian regulation, the so-called LD 221/2012) created between 2013 and 2014 (e.g., Cavallo et al., 2018) and from firms newly registered with the Italian Chambers of Commerce (Colombelli, 2016; Antonietti and Gambarotto, 2018). The sample includes 34,368 Italian start-ups; of these, 1,170 are innovative start-ups (ISUPs) playing a key role in the Italian economy. The Italian context should be relevant for many reasons. Italy has been characterised by an innovation gap that contributed to explaining the stagnant productivity and the low rate of growth over the last 20 years. Although the fraction of Italian firms that declare they are developing innovations is comparable to that of other European countries (Community Innovation Survey), the number of innovative breakthroughs is much lower (Finaldi Russo et al., 2016). The Italian context features a multitude of micro and small firms that are unable to bear the high fixed costs of R\&D investments, managerial teams of family firms that are reluctant to implement clear-cut innovative projects, and underdeveloped equity markets that are well tailored to finance innovation (Bugamelli et al., 2012). Against this background, at the end of 2012, Italian policy makers decided to improve the context for the founding and activity of ISUPs by the LD 221, referencing the policies implemented in the main European countries, specifically in the UK, where, under the Seed Enterprise Investment Scheme, relevant benefits are given to investors in ISUPs (Magliocco and Ricotti, 2013).

The LD 221 register offers the chance to employ an ex ante objective measure of innovativeness to account for the associated uncertainties and to avoid the survivorship bias of ideas. Based on the eligibility criteria identified by policy makers, our analysis considers different types of innovation (Dziallas and Blind, 2019) as antecedents of firm growth: (1) the innovation orientation of the venture (e.g., research doctorate or master's degree of the work force), (2) the inputs dedicated to an innovation process (e.g., R\&D and innovation expenditures), and (3) the outputs (e.g., patents) derived from an innovation process (Rosenbusch et al., 2011). Thus, we examine whether an innovation orientation, innovation process inputs or a focus on innovation process outputs leads to diverging growth effects (e.g., Roberts, 1990; Wolff, 2007).

Regression models and propensity score matching are used to reveal systematic differences in growth between ISUPs and non-innovative start-ups (e.g., Stephan, 2014). We use propensity score matching to "correct" the estimation of the treatment effect of innovation, controlling for the existence of such confounding factors.

Our findings suggest that innovativeness supports the growth of new ventures. Specifically, regarding the factors affecting the impact of innovation, we find that the effect of innovation inputs, such as R\&D and innovation expenditures, is greater than the innovation outputs, such as patents. We provide evidence of the growth implications of start-ups that traditionally make a significant contribution to economic growth (Terziovski, 2010; Wright et al., 2015). Furthermore, our findings are related to the start-up stage more than to the factors affecting new venture generation. Moreover, we contribute to the existing limited research on the innovation-performance relationship in new ventures that shows mixed results, and we extend the innovation implications research (Love and Roper, 2015).

Our conclusions provide suggestions for policy makers and entrepreneurs regarding the innovation decisions to configure ex ante appropriate actions for the growth of the new ventures. In addition to prior analyses on the effectiveness of Italian regulations in fostering the creation of the ISUPs, we contribute to knowledge on the subsequent ability of ISUPs to create value after their foundation.

Overall, our paper complements existing theories and studies on innovation in four main aspects. Our study is the first to use the new objective measure of start-up innovation, 
EJIM

24,5

1528

available from the LD 221 register, to examine the relationship between innovation and growth. Second, different types of innovation are investigated as antecedents of firm growth, helping us to explore further the quality of the innovativeness and its impact. Third, we employ propensity score matching that favours revealing systematic differences in growth between ISUPs and non-innovative start-ups. Fourth, the results of our study are the first to offer evidence on the effectiveness of the new Italian sustaining ISUPs policy.

This paper is structured as follows: in Section 2, we describe the theoretical background; in Section 3, we describe the dataset and explain our research methodology; in Section 4, we present our results; and in Section 5, we discuss the results and present conclusions, implications and limitations.

\section{Background}

Start-ups are firms that are in the early stages of their development. ISUPs recombine existing knowledge in innovative ways and invest in risky activities such as R\&D and patents (Acs et al., 2009). This study reviewed the theoretical and empirical literature relating to ISUPs to analyse whether innovative new ventures develop better performance than non-innovative new ventures. Nevertheless, few studies have investigated the effects of innovativeness on the growth of start-ups, and the existing studies show conflicting results.

The available literature sets forth a number of theoretical arguments explaining why the relation between start-ups' innovativeness and their performance, including growth, might be either positive or negative (e.g., Sarkar et al., 2006; Wagner and Cockburn, 2010). More specifically, scholars suggest that innovativeness should be a crucial element in the achievement of high growth for new ventures (Audretsch, 2004; McEvily et al., 2004; Shoham and Fiegenbaum, 2002; Roberts, 1999; Banbury and Mitchell, 1995). Theoretical arguments suggesting a positive link between innovativeness and firm growth argue that innovativeness can enhance firms' market power (Schumpeter, 1934), improve competitiveness (Porter, 1980; Nelson and Winter, 1982), reduce costs (Cohen and Klepper, 1996b; Nelson and Winter, 1982), develop dynamic capabilities (Teece et al., 1997; Eisenhardt and Martin, 2000) and enhance absorptive capacity (Zahra and George, 2002). However, different arguments suggest a negative effect of innovativeness on growth. The negative effect can be related to resistance to innovation adoption (Ram and Jung, 1991; Hultink and Atuahene-Gima, 2000; Damanpour, 1991); the high failure rates of innovations (Crawford, 1979; Berggren and Nacher, 2001); riskier, more complicated and less linear start-up processes (Samuelsson and Davidsson, 2009); more unpredictable returns (Scherer and Harhoff, 2000); and few collateralisable assets and long and uncertain payback periods (Brown et al., 2012; Minetti, 2011). Therefore, ISUPs have more limited access to external financing, which leads to a greater likelihood of failure (Berger and Udell, 2006). In addition, the successful development and introduction of innovations demand special organisational resources and capabilities to generate and appropriate the benefits of innovation (Schumpeter, 1934; Thornhill, 2006; Branzei and Vertinsky, 2006; Sethi and Sethi, 2009; Junkunc, 2007; Howell et al., 2005).

The prevailing view in the empirical literature appears to be that there is a positive association between firms' innovativeness and their subsequent survival. Cefis and Marsili (2006) explore the relationship between innovation and the survival probability of manufacturing firms. Based on data from the Netherlands, the authors' results show that innovation has a positive and significant effect on firm survival. Specifically, start-ups are the most exposed to the risk of exit but are also the firms that most benefit from innovation, contributing to their market survival. Helmers and Rogers (2010) analyse the survival of new ventures. Based on data from 162,000 British companies, the authors found that innovation is significantly positively correlated with survival. Their findings also highlight substantial differences in survival probabilities across sectors. Rosenbusch et al. (2011) develop a metaanalysis of the relationship between performance and innovation in SMEs. Specifically, the 
scholars provide an aggregate analysis of 46 empirical studies on the innovation-performance relationship in SMEs. Their research suggests that innovation creates value for SMEs and that innovation specifically has a stronger impact on younger firms. The authors argue that the flexibility of new firms might be beneficial. Colombelli et al. (2016) analyse the survival of ISUPs, focusing on the role of product innovation and process innovation, based on a sample of 1190 young French firms. The evidence suggests that ISUPs survive longer than their noninnovative counterparts. Moreover, the results show that process innovation plays a key role and is more beneficial than product innovation for start-up survival. With reference to Italy, Hall et al. (2008) find a positive contribution of product innovation on employment growth; as other researchers have found, Hall et al. (2008) state that process innovation has little displacement effect in Italy and that product innovation increases employment, but the productivity decline during the period seems to come largely from non-innovating firms. Block et al. (2016) analyse the performance-innovation relationship in start-ups through a summary of the academic knowledge of innovative entrepreneurship from 102 empirical studies published in primary economics and management journals. Overall, the authors found that innovation has a positive effect on business performance, as demonstrated in various studies. Zhang et al. (2020) analyse whether innovation affects the growth of high-tech startups in the Chinese context. Data from more than 75,000 firms located in science parks are analysed by a discrete-time proportional hazards model. The results show that the benefit from innovativeness outweighs the cost.

Nevertheless, there is emerging empirical evidence supporting a negative relationship between innovativeness and performance and suggesting that these results may be context dependent and may not be applicable to younger firms (Boyer and Blazy, 2014; Hyytinen et al., 2015). Boyer and Blazy (2014) study the explanatory factors of ISUPs. Based on French data on micro enterprises, the scholars highlight that ISUPs have shorter survival times than non-innovative start-ups. This result depends on greater uncertainty in the entrepreneur's perception of his or her propensity to survive. Moreover, this study contributes to unveiling the relative impact of many determinants on the survival of non-innovative start-ups. Hyytinen et al. (2015) suggest that start-up innovativeness is negatively associated with performance. Specifically, based on Finnish data, the scholars find a lower survival rate for ISUPS. The authors explain that these findings are related to the higher risks related to innovation and the more complicated start-up process for innovative firms (Buddelmeyer et al., 2010; Forlani and Mullins, 2000). Of course, the authors' findings do not support policy measures to push innovation in new ventures.

Recent studies (Rosenbusch et al., 2011; Hyytinen et al., 2015) agree on the positive effect of innovation but, at the same time, show that the type of innovation that is adopted is equally important. From a production process perspective (Parthasarthy and Hammond, 2002), innovation inputs (e.g., innovation investments or innovation capabilities) can be distinguished from innovation outputs (e.g., number of patents or new products). This distinction is important because the relationship between firm performance and innovation takes on a different intensity based on the type of innovation analysed (Rosenbusch et al., 2011).

Overall, studies on the effects of innovativeness on start-up performance mainly find a positive effect of innovation on business performance. Innovativeness is generally defined in a subjective way, while performance is frequently investigated as firm survival. Contrasting results are increasingly explained by the presence of several circumstances affecting the potential benefit of innovation. Studies suggest that the overall impact of innovation on performance is an aggregate effect resulting from both positive and negative mediating effects, which are additionally moderated by contextual factors. There is a need for studies based on objective definitions of innovativeness and growth measures that investigate both growth outcomes and contextual factors. 
EJIM

24,5

1530

\section{Methods and data}

\subsection{Data}

The aim of the analysis is to evaluate the impact of innovativeness on the growth of Italian start-ups. We adopt the definition of innovativeness dictated by the Italian Legislative Decree n. 221/2012 (LD 221) the so-called growth 2.0 decree. LD 221 regulates the Italian register of ISUPs both by establishing the requirements to define an enterprise as innovative and by regulating several incentives [1] for companies registered as ISUPs.

According to LD 221, a start-up is defined as "innovative" if it has at least one of the following 3 requirements:

(1) R\&D expenses must be equal to or greater than $15 \%$ of the higher value of either costs or the total value of production;

(2) at least $1 / 3$ of the company's personnel must have earned a research doctorate (or are earning a research doctorate); alternatively, at least $2 / 3$ of the work force must have obtained a master's degree;

(3) the company must be the owner or licensee of at least one industrial property.

For registration in the Italian register of ISUPs, in addition to compliance with the requirements relating to the innovative nature of the firm, compliance with the following formal and substantial restrictions is required:

- the company must be a limited company;

- the exclusive or predominant social object must be the development, production and marketing of innovative products or services with high technological value;

- the head office must be in Italy or in an EU country;

- the company must have been established for no more than 60 months;

- the value of production obtained in the annual financial period, starting from the second year, must not exceed 5 million euro;

- the company must not distribute profits for the entire duration of the preferential regime;

- the company must not arise from a merger, spin-off or transfer of a company/branch of a company.

This study compares the growth of ISUPs with the growth of a group of companies with similar characteristics - in size, age and access to the stock exchange markets - but that do not meet the requirements for innovativeness as prescribed by LD 221. We use a new dataset obtained through merging data from the ISUP registers of the Italian Chambers of Commerce and the Italian Ministry for Economic Development [2] with those collected in the financial database AIDA - Bureau Van Dijk.

The final dataset includes two cohorts of ISUPs (innovative and non-innovative) established in 2013 and 2014 that meet the following criteria: the value of production obtained in the annual financial period does not exceed 5 million euro, there are fewer than 50 employees, and the company is unlisted. The dataset is therefore composed of 34,368 companies; $1,170(3.4 \%)$ of these are ISUPs (according to DL.221) [3].

We use the growth rate of the revenue from sales as a measure of company performance. Although growth has a complex and multidimensional nature that is difficult to address using any single measure, revenues from sales are one of the most appropriate and diffused financial measures for start-ups (Autio et al., 2000; Weinzimmer et al., 1999). The growth rate of the 
revenue from sales is a proxy for the degree of market acceptance of a new venture (Clarysse et al., 2011). Revenue data are often a preferred measure of firm growth of start-ups because, first, they are relatively accessible and, second, they are used for all firms (Hoy et al., 1992). Indeed, revenues are relatively insensitive to capital intensity and the degree of integration (Delmar et al., 2003). The most diffused non-financial alternative measure of start-up growth is growth in employees (Chandler and Hanks, 1993); for many authors, this measure is a usefuland direct indicator of growth to determine the increase in managerial complexity (Delmar et al., 2003).

A three-year growth rate is computed for the two cohorts (2013 and 2014) of innovative and non-innovative ISUPs.

The growth rate is computed as the difference between the log of a firm's total revenue from sales in the last three years according to the following formulation:

$$
\ln \left(\frac{\text { Revenue }_{\text {lastyear }}-\text { Revenue }_{-3 y \text { ears }}}{\text { Revenue }_{-3 \text { years }}}\right)
$$

The effect of innovation on growth is assessed through a dummy that takes the value 1 if the company is an ISUP ( 0 otherwise). In addition, we account for a set of variables relating to the size of companies and another set related to the propensity for R\&D while controlling, at the same time, for a set of structural controls (see par.3.3).

In Table 1, the distribution of start-ups based on the NACE rev2 classification is reported. Almost $70 \%$ of innovative start-ups are concentrated in the sectors of "Financial and

\begin{tabular}{|c|c|c|c|c|c|c|}
\hline \multirow[b]{2}{*}{ Section } & \multirow[b]{2}{*}{ Sector } & \multicolumn{2}{|c|}{ Not innovative } & \multicolumn{2}{|c|}{ Innovative } & \multirow[b]{2}{*}{ Total } \\
\hline & & $N$ & $\%$ & $n$ & $\%$ & \\
\hline A & Agriculture, forestry and fishing & 68 & 0.20 & 0 & 0.00 & Jo \\
\hline B & Mining and quarrying & 490 & 1.48 & 5 & 0.43 & 495 \\
\hline $\mathrm{C}$ & Manufacturing & 22 & 0.07 & 0 & 0.00 & 22 \\
\hline $\mathrm{D}$ & Electricity, gas, steam and air conditioning supply & 4,308 & 12.98 & 186 & 15.90 & 4,494 \\
\hline $\mathrm{E}$ & $\begin{array}{l}\text { Water supply; sewerage, waste management and } \\
\text { remediation activities }\end{array}$ & 267 & 0.80 & 7 & 0.60 & 274 \\
\hline $\mathrm{F}$ & Construction & 174 & 0.52 & 2 & 0.17 & 176 \\
\hline G & $\begin{array}{l}\text { Wholesale and retail trade; repair of motor vehicles } \\
\text { and motorcycles }\end{array}$ & 4,112 & 12.39 & 24 & 2.05 & 4,136 \\
\hline $\mathrm{H}$ & Transportation and storage & 8,419 & 25.36 & 59 & 5.04 & 8,478 \\
\hline I & Accommodation and food service activities & 1,352 & 4.07 & 2 & 0.17 & 1,354 \\
\hline 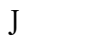 & Information and communication & 2,998 & 9.03 & 6 & 0.51 & 3,004 \\
\hline $\mathrm{K}$ & Financial and insurance activities & 1,653 & 4.98 & 532 & 45.47 & 2,185 \\
\hline $\mathrm{L}$ & Real estate activities & 429 & 1.29 & 1 & 0.09 & 430 \\
\hline $\mathrm{M}$ & Professi & 1,701 & 5.12 & 1 & 0.09 & 1,702 \\
\hline $\mathrm{N}$ & and support service activities & 2,667 & 8.03 & 292 & 24.96 & 2,959 \\
\hline O & $\begin{array}{l}\text { Public administration and defence; compulsory } \\
\text { social security }\end{array}$ & 1,935 & 5.83 & 31 & 2.65 & 1,966 \\
\hline $\mathrm{P}$ & Education & 3 & 0.01 & 0 & 0.00 & 3 \\
\hline Q & Human health and social work activities & 387 & 1.17 & 9 & 0.77 & 396 \\
\hline $\mathrm{R}$ & Arts, entertainment and recreation & 739 & 2.23 & 6 & 0.51 & 745 \\
\hline $\mathrm{S}$ & Other service activities & 925 & 2.79 & 4 & 0.34 & 929 \\
\hline $\mathrm{T}$ & Activities of households as employers & 548 & 1.65 & 3 & 0.26 & 551 \\
\hline $\mathrm{U}$ & $\begin{array}{l}\text { Activities of extraterritorial organisations and } \\
\text { bodies }\end{array}$ & 1 & 0.00 & 0 & 0.00 & \\
\hline Tot & & 33,198 & 100.00 & 1,170 & 100.00 & 34,368 \\
\hline
\end{tabular}

Note(s): (*) The companies included in the following sections: A, B, C, E, F, I, J, L, M, P, Q, R, S, T, U, have been eliminated from the analysis because the number of innovative companies is less than 10

The early growth of start-ups

\section{.}


EJIM

24,5

1532

insurance activities" and "Administrative and support service activities" (45.47\% and $24.96 \%$, respectively), whereas non-innovative start-ups are mainly concentrated in the sectors of "Transportation and storage" $(25.36 \%)$ and "Electricity, gas, steam and air conditioning supply" (12.98\%).

It should be noted that the type of economic activity strongly characterises innovative companies, which are concentrated in a few production sectors. With this aspect in mind, to highlight the net effect of innovation on company growth, sectors characterised by a zero or irrelevant presence of ISUPS $(<10)$ have been excluded from the sample of analysis, and specific econometric techniques (propensity score approach, see Section 3.2) capable of accounting for the structural differences between the two subsamples of companies (innovative and non-innovative) are used.

We analyse the effect of innovativeness by controlling for several factors (Table 2) that prior studies suggest should have mediating effects on ISUP growth (e.g., Colombelli et al., 2016; Hyytinen et al., 2015; Rosenbuch et al., 2011). These covariates may also be of interest for explaining the difference due to innovativeness.

We identify two different typologies of explanatory variables. The first group of variables encompasses the variables related to company size (Holmes et al., 2010; Reid, 1995). From this perspective, the following covariates have been included in the model: total assets (expressed in thousands of euro), number of employees and share capital (expressed in thousands of euro). The descriptive statistics, reported in Table 1, show that ISUPs are characterised by a smaller size than non-innovative start-ups; in particular, the average number of employees of innovative companies is almost half that of non-innovative companies, and both total asset values that share capital are significantly lower for innovative companies (Freel, 2000; Cozza et al., 2012).

The second group of variables is related to R\&D activities. We control for the following variables (expressed in thousands of euro): expenses for industrial patent rights and R\&D costs. As expected, the Italian ISUPs are more oriented towards investments in R\&D and show a statistically significant difference compared to the non-innovative start-ups in terms of expenses for patents and the costs related to R\&D.

Finally, we consider a set of control variables that includes: (1) the debt equity ratio, which measures the degree to which a company is financing its operations through debt versus wholly owned funds; (2) territorial dummies (NUTS 3-level) [4] to account for the significant territorial differences, in terms of socio-economic development and structural endowment, between the Italian provinces; and (3) sectorial dummies (according to the sections of NACE rev.2) to capture differences between economic sectors of activity.

\begin{tabular}{|c|c|c|c|c|c|c|c|c|c|}
\hline & \multirow[b]{2}{*}{ Variable } & \multirow[b]{2}{*}{ Label } & \multicolumn{2}{|c|}{ Pooled sample } & \multicolumn{2}{|c|}{ Innovative } & \multicolumn{2}{|c|}{ Non innovative } & \multirow{2}{*}{$\begin{array}{l}\text { Difference } \\
\text { (Innov-not } \\
\text { innov.) }\end{array}$} \\
\hline & & & Mean & SD & Mean & SD & Mean & SD & \\
\hline & lngrow & $\begin{array}{l}\text { Growth of Revenues } \\
\text { from sales (ln) }\end{array}$ & 2.47 & 2.46 & 3.47 & 1.99 & 2.44 & 2.47 & $1.03 * * *$ \\
\hline & to & Total assets & 148.82 & 5225.89 & 81.11 & 312.71 & 151.20 & 5316.84 & -70.09 \\
\hline & $\mathrm{em}$ & $\begin{array}{l}\text { Number of } \\
\text { employees }\end{array}$ & 4.78 & 7.10 & 3.02 & 5.63 & 4.85 & 7.14 & $-1.82 * * *$ \\
\hline \multirow{5}{*}{$\begin{array}{l}\text { Table } 2 \text {. } \\
\text { Descriptive statistics of } \\
\text { the explanatory } \\
\text { variables for the pooled } \\
\text { sample and for } \\
\text { innovative and not } \\
\text { innovative firms }\end{array}$} & sh_ca & Share capital ${ }^{(1)}$ & 54.31 & 2588.23 & 29.68 & 178.69 & 55.17 & 2633.22 & -25.5 \\
\hline & debt_eq & Debt/ & 1.77 & 23.06 & 0.95 & 18.44 & 1.80 & 23.20 & -0.86 \\
\hline & patents & $\begin{array}{l}\text { Equity rati } \\
\text { Patents (1) }\end{array}$ & 0.99 & 41.96 & 4.23 & 27.19 & 0.88 & 42.38 & $3.35 * * *$ \\
\hline & $\mathrm{R} \& \mathrm{D}$ & $\mathrm{R} \& \mathrm{D}$ costs ${ }^{(1)}$ & 1.53 & 29.92 & 12.89 & 66.90 & 1.13 & 27.64 & $11.76^{* * * *}$ \\
\hline & \multicolumn{9}{|c|}{$\begin{array}{l}\text { Note(s): }{ }^{(1)} \text { Data in thousands of euro, *: significant at } 10 \% \text { level; **: significant at } 5 \% \text { level, ***: significant at } \\
1 \% \text { level }\end{array}$} \\
\hline
\end{tabular}




\subsection{Methods}

We investigate the effect of innovativeness on start-up performance by comparing the growth rate of the revenue from sales of innovative and non-innovative firms. First, a raw estimate of this differential is obtained by a simple growth function:

$$
\Delta Y_{i}=\beta_{0}+\beta_{1} I_{i}+\varepsilon_{i}
$$

where $y_{i}$ is the growth of the $i$-th firms, $I_{i}$ is a dummy variable for innovativeness (not innovative $=0$, innovative $=1$ ), and $\varepsilon_{i}$ is the error component. The coefficient $\beta_{1}$ from a classical OLS regression provides a first estimate of the size of the average effect of innovativeness, although it does not allow us to control for other factors that may influence firms' growth. For that reason, we adopt a "full" growth function to obtain an adjusted estimate of the effect of innovativeness, controlling for a set of $K$ covariates focused on several firms' characteristics. In addition, consistent with Colombelli (2016), we include both regional dummy fixed effects $\left(\theta_{j}\right)$ to account for the effect of the local context on firm growth and a vector of sectorial dummies $\left(\delta_{r}\right)$ to capture the difference between the economic sector of activity (according to NACE rev.2):

$$
\Delta Y_{i}=\beta_{0}+\beta_{1} I_{i}+\sum_{k=2}^{K} \beta_{k} x_{i k}+\theta_{j}+\delta_{r}+\varepsilon_{i}
$$

Subsequently, we exploit the data from the Italian register of ISUPs, from which it is possible not only to assess the marginal effect of innovativeness but also to analyse the role that the type of innovation plays in company growth. In this perspective, the "generic" variable relating to the innovative nature of the company $\left(I_{i}\right)$ has been replaced with three dummies, which, based on the classification proposed by Rosenbusch et al. (2011), describe the effect of the type of innovation adopted by the companies. The inclusion of these variables leads to the following growth function:

$$
\Delta Y_{i}=\beta_{0}+\beta_{1} \mathrm{INP}_{\mathrm{i}}++\beta_{2} \mathrm{OUT}_{\mathrm{i}}+\beta_{3} \mathrm{OR}_{\mathrm{i}}+\sum_{k=4}^{K} \beta_{k} x_{i k}+\theta_{j}+\delta_{r}+\varepsilon_{i}
$$

where the input innovation is described by a dichotomous indicator (INP) that takes a value of 1 if the R\&D expenses of ISUP are equal to or greater than $15 \%$ of the higher value of either costs or the total value of production; the output innovation is included through a dummy (OUT) equal to 1 if the ISUP is the owner or licensee of at least one industrial property; and finally, the orientation innovation (OR) is modelled by a dummy that takes a value of 1 if at least $1 / 3$ of the ISUP's personnel have earned a research doctorate or at least $2 / 3$ of the work force have obtained a master's degree.

In addition, to analyse whether and how the effect of innovativeness (see eq. (3)) varies over the whole distribution of firm growth, an unconditional quantile regression (UQR) is employed (Firpo et al., 2009).

This method requires the estimation of a recentered influence function (RIF) for every quantile of interest $Q_{\tau}$ :

$$
\operatorname{RIF}\left(\Delta y ; \widehat{Q}_{\tau}\right)=\widehat{Q}_{\tau}+\frac{\tau-F\left(y \leq \widehat{Q}_{\tau}\right)}{\widehat{f}_{y}\left(Q_{\tau}\right)}
$$

where $\widehat{Q}_{\tau}$ is the sample $\tau$-th quantile, $\widehat{f}_{y}\left(Q_{\tau}\right)$ is a standard non-parametric density estimator (i.e., a kernel), and $F$ is an indicator function.

For every quantile, the estimated RIF is then regressed on the chosen covariates using a standard OLS estimator. The estimated coefficients capture the marginal impact of the 
EJIM

24,5

1534

covariates on the quantiles of the unconditional distribution of the growth rate. In other words, they provide information on the effect of innovativeness among low-performing firms (at the lowest quantiles) as well as among high-performing firms (at the highest quantiles). In contrast, a classical OLS regression gives information on the impact of the covariates only for an average firm, while the UQR allows for the assessment of whether any difference in the growth of innovative and non-innovative start-ups with the same observed characteristics remains constant across growth levels or if it instead shrinks or grows.

To give robustness to the results from the regression analysis (OLS and UQR), we compare the distributions of the growth variable between the populations of innovative and non-innovative start-ups. Because these two populations are different, appropriate methodologies are needed to isolate the impact of innovativeness on start-up growth.

In this framework, the results from traditional regression methods are often unreliable because of the nonrandom assignment of the subjects to the treatment and control groups, which leads the estimation of the treatment effect to be biased based on the existence of confounding factors. As underlined by Cozza et al. (2012), “... the driving force that pushes firms to engage innovation activities can be seen as a self-selection mechanism which makes the estimation of its economic impact trickier if confounding factors affecting this mechanism also affect the economic performance of the firms (e.g. managerial abilities, unobservable changes in the firm's operating environment or in the business cycle, etc.)".

Therefore, we adopt non-parametric propensity score matching (PSM), which has become popular in the context of programme evaluations (Becker and Ichino, 2002; Rosenbaum and Rubin, 1983), to improve the comparability of the two populations by using observed characteristics (named confounders) to reduce the bias in measuring the effect of a treatment; these are increasingly used in ISUP studies (e.g., Finaldi Russo et al., 2016; Stephan, 2014) and, more generally, to analyse the effect of public policies on firm behaviour (Engel et al., 2016). Compared to the OLS estimators, the non-parametric matching approach has the additional advantage of not requiring a particular specification for the relationship between innovativeness and start-up growth.

In this sense, propensity scoring attempts to simulate the randomisation of subjects as in randomised controlled trials, which allows the "correction" of the estimation of the treatment effect of innovation when controlling for the existence of confounding factors.

The underlying principle of PSM consists of comparing treatment and control units (innovative and non-innovative firms) that are similar in terms of their observable characteristics. The main aim is to assess the expected effect of innovativeness (treatment) for the treated population (ISUPs). This estimated effect is the average treatment effect on the treated (ATT) population, which is defined as:

$$
\mathrm{ATT}=E\left(Y_{1}-Y_{0} \mid D=1\right)=E\left(Y_{1} \mid D=1\right)-E\left(Y_{0} \mid D=1\right)
$$

where $Y_{1}$ is the outcome for innovative start-up and $Y_{0}$ is the outcome for non-innovative start-ups, while $D$ is the indicator of treatment $(D=1$ for the treated firms, $D=0$ for the non-treated firms). The counterfactual outcome $E\left(Y_{0} \mid D=1\right)$ is not observable, and it is estimated through a counterfactual sample of firms (the control group) by pairing each recipient firm with a non-treated firm through matching econometric estimators.

The control group, therefore, is constituted by non-innovative firms whose distribution of observed characteristics is as similar as possible to that of the innovative firms.

To match the treated and control units, Rosembaum and Rubin (1983) proposed the use of the propensity score, i.e., the probability of assignment to the treatment group (innovative $=$ "yes"), conditional on a vector of observed covariates $X$, which is written as $P(D=1 \mid X=x)$. Conditional on the propensity score, the distribution of the observed covariates is the same for $D=1$ and $D=0$ (balancing hypothesis), and as proposed by Rubin (1997), 
it approximates the randomisation of the assignment of firms to these groups. The propensity score was calculated for each firm in the treated (innovative = "yes") and comparison-group (innovative = "no") samples using a standard logit model[5]. The underlying principle has been to include the logit regression variables that are not influenced by the treatment to meet the conditional independence assumption (CIA).

We construct the match for each innovative (treated) start-up as a weighted average over the outcomes of non-innovative (control) start-ups, where the weights depend on the distances between the estimated propensity scores. The more similar the firms are in terms of these propensities, the higher the weight.

$$
\mathrm{ATT}=E\left\{E\left(Y_{1} \mid D=1, p(X)\right)-E\left(Y_{0}|D=0, p(X)| D=1\right)\right\}
$$

To estimate the average effect of the treatment, an area of common support is used, which enables us to eliminate those firms that present poor matching. Three alternative matching algorithms are adopted. The first is the nearest neighbour matching (NNM), which consists of an algorithm that matches each treated start-up (innovative firm) with the non-treated startup displaying the closest propensity score. A limitation of the NNM is that fewer observations are used to construct the counterfactual for each treated start-up. Therefore, as robustness checks, we also use radius matching and kernel matching methods. With radius matching, each treated unit is matched only with the control units whose propensity scores fall into a predefined neighbourhood of the propensity score of the treated unit. With kernel matching, every treated unit is matched with a weighted average of all the control units with weights that are inversely proportional to the distance between the propensity scores of the treated units and the controls.

\section{Results}

\subsection{OLS and unconditional quantile models to assess the effect of innovativeness}

The first set of results concerns the estimation of growth models using classical OLS regression for the entire sample of firms. The inclusion of an innovativeness dummy (innov) allows us to assess the gap in growth between innovative and non-innovative start-ups while controlling for the effects of other factors. We analyse the growth determinants in a stepwise fashion. The first baseline model includes the innovativeness dummy and the set of control covariates (regional fixed effects, sectorial dummies and the debt/equity ratio), thus producing a first estimate of the average difference. Additionally, we add each group of variables one at a time to assess the influence of each group of covariates on both growth and innovativeness. Finally, a full model that includes all the variables is estimated. The results of the OLS regression (Table 3) show that the observed average gap in growth between innovative (group 1) and non-innovative start-ups (group 0) is 1.271 (model 1).

The effect of innovativeness is still significant when controlling for the dimensional covariate (mod.2); at the same time, the results of model 2 confirm that the size of firms influences their performance. Therefore, larger companies have higher growth margins.

In model 3 , the variables related to R\&D are added. On the one hand, all the covariates related to R\&D have a significant impact on the growth of companies. On the other hand, the effect of innovativeness is not sensitive to adding this set of covariates, although its magnitude has been slightly reduced.

Model 4a encompasses both the control variables and the two groups of covariates included in the previous models. Additionally, checking for all the variables used in previous models, the effect of innovativeness on improving company growth is statistically significant, and its magnitude is almost unchanged.

Lastly, the role of the type of innovation is analysed in model $4 \mathrm{~b}$, where $t 3$ dummies relating to the type of business innovation are included in place of the dummy $I_{i}$. As described
The early growth of start-ups 
$\underset{24,5}{\text { EJIM }}$

1536

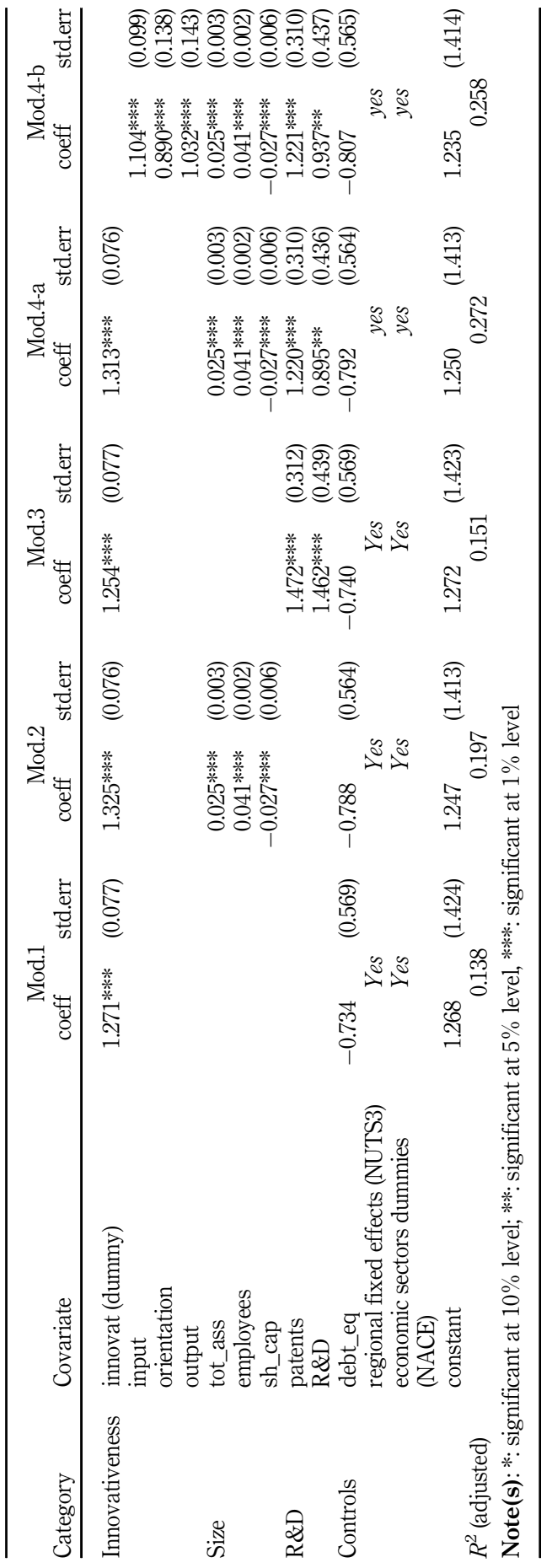

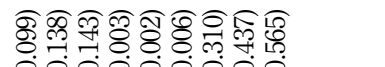

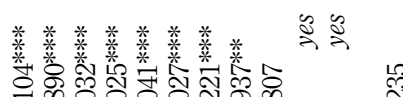

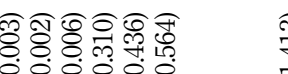

**** $\stackrel{2}{*}$

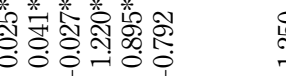

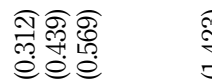

* 2 \&

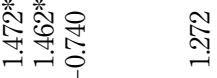

‡્木

औँ के

离

क़ิ

is $\rightarrow \infty$

范

กิ
Table 3.

Results from OLS regression models by macro-category of explanatory variables 
in section 3.2, the "input" dummy is related to the level of R\&D expenses (with respect to the total cost or the total value of the production), and the output dummy considers the ownership by the ISUP of an industrial property as a proxy of the innovative capacity, while the orientation is described by the educational level of its staff.

The coefficients of the three dummies are all statistically significant even if the decomposition by type of innovation highlights that the highest effect on growth is linked to input innovation. Unlike those of prior studies (Rosenbusch et al., 2011; Wolff, 2007), these results show the potential return on investments in $R \& D$.

In addition to the OLS estimates, we employ a quantile regression approach to analyse the effect of innovativeness at different percentiles of the growth distribution. Figure 1 shows the unconditional effect expressed by the coefficient of the innovativeness dummy in the full UQR model.

The full model highlights that innovativeness seems to have the greatest influence on companies with low-middle average growth rates, while its effect is significantly reduced when considering top performing firms. Indeed, from the 70th percentile onwards, there is a decrease in the effect of innovation that appears to be nonsignificant at the last percentiles (above the 80th percentile).

\subsection{The effect of innovation on start-up growth using propensity score matching}

Table 3 reports the results from the propensity score analysis based on the three approaches described in section 3.2. The standard error of each estimate of ATT is obtained analytically (assuming that the weights are fixed and the outcomes are independent across units) and at same time is computed by a bootstrap approach with 100 replications. We checked the balance between treated and untreated subjects after matching by computing the differences in the means, the reduction in bias resulting from the matching, and the significance for the unmatched sample and the matched sample in both the experimental group (ISUPs) and the control group (non-innovative firms). Most of the variables are significantly different, and we found that the matching approach markedly improved the balance of all the covariates (Figure 2) and that, without the matching, the estimations would have been biased.

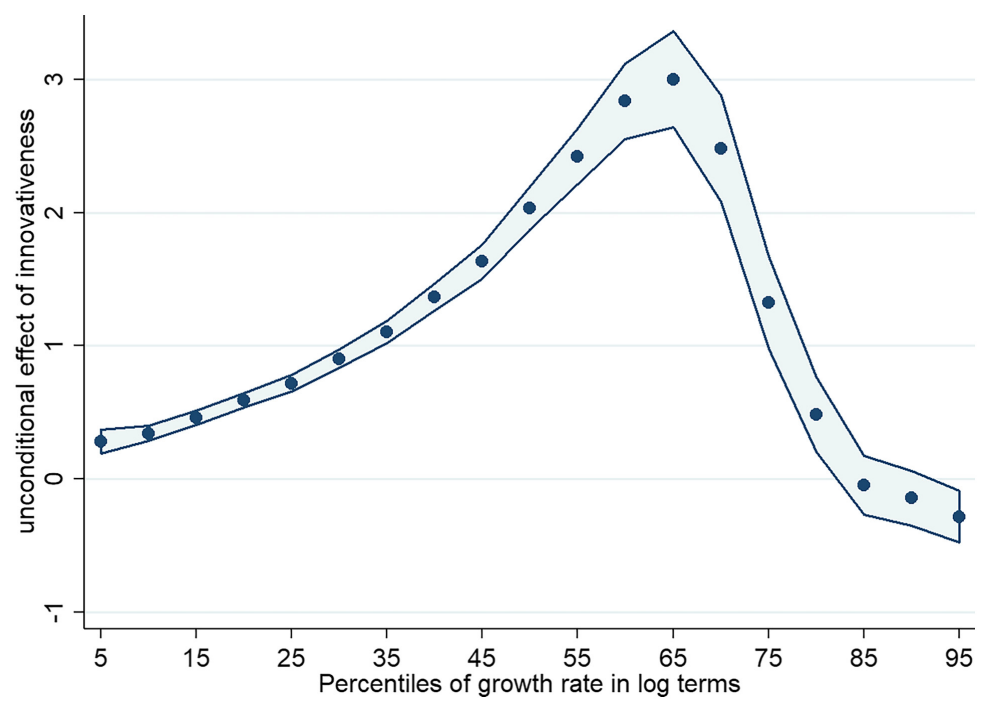

The early growth of start-ups

1537 
EJIM

24,5

\section{8}

Figure 2.

Bias reduction pre and post matching

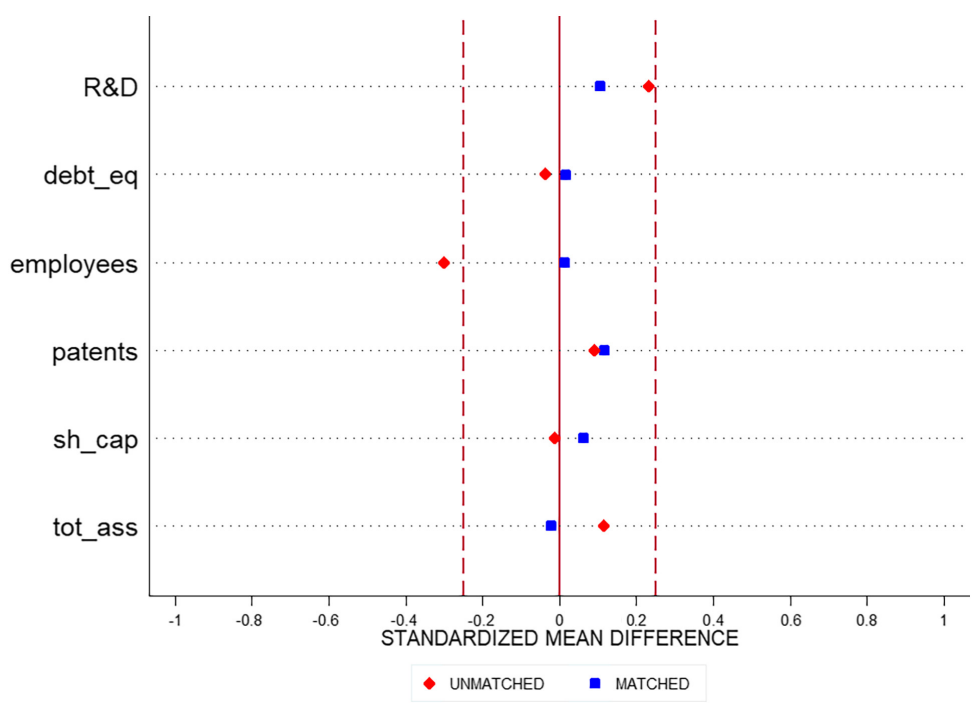

Overall, the results for the ATT show that innovative start-ups experienced higher growth rates than non-innovative start-ups. The effect of innovativeness is always significant regardless of the matching algorithm; it is worthwhile to emphasise the similarity between the ATT estimates obtained with radius and kernel matching methods in terms of standard errors (Table 4).

It is likely that the use of a larger number of control units is able to ensure more robust estimates and hence an increase in the statistical significance of the estimators (bearing in mind that the different requirements for the construction of the control group differ according to the estimator used).

The ATT estimates from the three alternative algorithms show that many comparison units overlap with the treatment group; therefore, it seems that PSM methods are able to yield reasonably accurate estimates of the effect of innovativeness on start-up growth. Although, from a methodological and interpretative point of view, it is not possible to directly compare the regression coefficients and the ATT estimates, nevertheless the broad picture that emerges is substantially clear and points at demonstrating that the positive effect of the innovation highlighted by the OLS and quantile regression results is confirmed by the estimates obtained through the PSM approach, and these results are also robust with respect to the choice of the matching method.

\begin{tabular}{lccccccr}
\hline $\begin{array}{l}\text { Matching } \\
\text { method }\end{array}$ & $\begin{array}{c}\text { Treated } \\
\text { units }\end{array}$ & Controls & \multicolumn{2}{c}{ std.err. } & \multicolumn{2}{c}{$t$-statistics } \\
NNM & 1,170 & 1,692 & 1.279 & 0.097 & 0.201 & 13.170 & 5.871 \\
RADIUS & 959 & 22,121 & 1.063 & 0.068 & 0.099 & 15.556 & 9.883 \\
KERNEL & 1,170 & 30,639 & 1.232 & & 0.112 & & 10.923
\end{tabular}

Table 4.

Note $(\mathbf{s}):(*)$ Balancing properties and common support
applied with replacement. Bootstrap replications $=100$ 


\section{Discussion and conclusions}

Some authors have investigated the innovation-performance relationship in start-ups (e.g., Colombelli et al., 2016). Nevertheless, despite scholars' efforts on the topic, the existing research, on one hand, shows contrasting results and, on the other hand, is partially incomplete because it does not analyse in detail the mediating effects of factors that can affect the innovation-performance relationship. Moreover, scholars often analyse the relationship between innovativeness and growth only through subjective definitions of ISUPS.

We insert our work into this aforementioned literature stream, trying to fill this gap by investigating and quantifying the effect of the relationship between start-up innovativeness (as prescribed by LD 221) and early-stage growth. To achieve our aim, we analyse whether innovation drives start-up growth in a sample of Italian ISUPs. The data confirm that Italian ISUPs are more oriented towards investments in R\&D than their counterparts but also highlight that ISUPs are smaller in size than non-innovative start-ups.

Our findings contribute to the literature by providing an explicit indication about the relevance of innovativeness for faster growth in the start-up stage. We contribute to the innovation literature, and we document a positive association between innovativeness and growth (Dosi et al., 1995; Santi and Santoleri, 2017). Our findings, supporting theoretical arguments asserting a positive link between innovativeness and firm growth, seem to confirm the role of innovation for increasing market power (Schumpeter, 1934), improving competitiveness (Porter, 1980; Nelson and Winter, 1982), reducing costs (Cohen and Klepper, 1996a, b; Nelson and Winter, 1982), developing dynamic capabilities (Teece et al., 1997; Eisenhardt and Martin, 2000), and enhancing absorptive capacity (Zahra and George, 2002). Moreover, the results suggest that different types of innovations differently support the growth of ISUPs (Hyytinen et al., 2015). In particular, regarding the innovativeness of start-ups, we find that the effects are statistically significant. Indeed, the effect of innovation inputs is greater than that of innovation outputs. These findings are consistent with those of Rosenbusch et al. (2011), suggesting that SMEs benefit significantly more from a strategic innovation orientation than from simply focusing on developing innovative products. Moreover, innovativeness seems to have the greatest impact on low-growth start-ups, suggesting the existence of diverse growth regimes across time (Audretsch and Fritsch, 2002). Furthermore, consistent with Hyytinen et al. (2015), there are relevant research implications for scholars: future analyses of the innovativeness-growth relation should pay careful attention to the empirical measures of innovativeness, analysing the differences between ex post indicators, which capture successful innovations and innovators, and ex ante indicators, which reflect the innovation orientation. Future analysis of potential biases and correlation risks should improve empirical analysis on innovation.

From a practical point of view, this work has both economic and social relevance. We provide effective evidence-based policy that contributes to maximising the potential of startups. We support recent research findings suggesting that "well-equipped" ISUPs may be an important stimulus for economic growth, while the effect of non-innovative new businesses, which replicate already-existing products and processes, is rather small or even negative (Audtresh et al., 2011).

We focus on Italian ISUPs in a local context in which ad hoc regulation sustaining ISUPs has only recently been established and there was a lack of evidence regarding the subsequent results. Thus, we provide a complementary contribution to the effectiveness and efficiency of innovation policies (Foreman-Peck, 2013) and to the broad literature on national systems of innovation (Acs et al., 2017). We integrate early studies on the effects of the new regulation, approved in Italy at the end of 2012, providing measures to foster ISUPs. Prior studies highlight the efficiency and effectiveness of the regulation in the creation of ISUPs (Antonietti and Gambarotto, 2018; Colombelli et al., 2016; Finaldi et al.,
The early growth of start-ups

1539 
EJIM

24,5

1540

2016). Our findings shed light on the subsequent post-foundation stage since "to be born is not enough" (Colombelli et al., 2016). Determining the success of government initiatives such as DL 221 is a difficult task. The findings allow us to expect positive feedback for this Italian innovation policy. The higher growth of ISUPs suggests that persisting with SME innovation policy should be the right move for contexts such as Italy, as long as activities facilitating the growth of ISUPs become important parts of policy makers' agendas (Czarnitzki and Delanote, 2015). Moreover, our results show an impact of innovation inputs that is greater than that of innovation outputs. An area for Italian policy-maker improvement would be to focus on measures sustaining firms investing in innovation inputs or innovation inputs and outputs together (Arundel et al., 2015). Indeed, since the DL 221 does not provide direct benefits to firm growth, and the ISUP register is a policy promoting the development of ISUPs (e.g., by increasing visibility and reducing bureaucratic constraints) and not aimed at creating new ventures, the DL 221 should be integrated with effective policies for entrepreneurship.

Nevertheless, this study has some limitations that should be addressed in future research.

From a methodological point of view, although the PSM offers several improvements to the assessment of the net effect of innovation, this methodology is not without limitations. In detail, it is worthwhile to note that analysis based on propensity score matching relies on the assumption of "selection on observables", and therefore, even if the AIDA dataset provides many matching variables, this does not guarantee that all the heterogeneity between innovative and noninnovative SMEs can be captured sufficiently. In this perspective, the results should be interpreted with some caution because the relationship between innovation and SME growth should be interpreted as correlational rather than causal. The empirical evidence presented here can be seen as exploratory in nature, while future research will concentrate on gaining a greater understanding of the (causal) mechanisms behind innovation (new datasets - possibly collected as panel data following cohorts of SMEs - will therefore be necessary in this further step). Despite this paper's descriptive purpose, policymakers and academics will be able to review and discuss its findings as a first step towards carrying out a more detailed causal analysis of the role that innovation can play to support the growth of SMEs. In addition, we cannot exclude that policies supporting innovative start-ups have produced limited indirect effects on ISUPs' growth. Because of the complex nature of ISUP growth, future research may improve the models and the operationalisation of some dimensions. Specifically, future studies could use alternative measures of growth to recognise the multidimensional nature of performance, such as growth in the number of employees or total assets responding to alternative perspectives of growth. Indeed, over time, since the establishment of the register of ISUPs, future research should embrace a longer time horizon to analyse the impact of innovativeness on the subsequent stages of the firm life cycle. Finally, future research should investigate reasons pushing firms towards (or away from) registration in the LD 221 register.

\section{Notes}

1. The incentives for companies registered as ISUPs include tax benefits for investors, zero-interest rate loans from public agencies, the chance to use flexible employment contracts, cheaper and easier administrative start-up procedures, tax credits on highly skilled personnel, support for internationalization strategies and easier failure procedures.

2. The data can be freely downloaded from the website http://startup.registroimprese.it

3. The sample of analysis does not consider, like ISUPS, the SMEs not included in the register established by the DL 221. The Aida data do not allow the estimation of the number of these missed registrations, but the numerous incentives granted to the companies in the register lead to the 
hypothesis that the number of these companies (which are not included in the register of Legislative Decree 221, even if they meet the requirements) is negligible for the purposes of this analysis.

4. According to the Nomenclature of Territorial Units for Statistics (NUTS), level 3 includes 103 Italian provinces.

5. In the logit model specification, the same covariates used in the OLS and quantile models are included. In addition, the square of the total assets and the interactions between patents and share capital; debt/equity ratio and licenses, trademarks and similar rights; debt/equity ratio and R\&D costs are introduced to improve the explicative power of the logit model.

\section{References}

Acs, Z.J. and Audretsch, D.B. (1988), "Innovation in large and small firms: an empirical analysis", American Economic Review, Vol. 78 No. 4, pp. 678-690.

Acs, Z.J., Braunerhjelm, P., Audretsch, D.B. and Carlsson, B. (2009), "The knowledge spillover theory of entrepreneurship", Small Business Economics, Vol. 32 No. 1, pp. 15-30.

Acs, Z.J., Audretsch, D.B., Lehmann, E.E. and Licht, G. (2017), "National systems of innovation", The Journal of Technology Transfer, Vol. 42 No. 5, pp. 997-1008.

Antonietti, R. and Gambarotto, F. (2018), "The role of industry variety in the creation of innovative start-ups in Italy", Small Business Economics, Vol. 54, doi: 10.1007/s11187-018-0034-4.

Arundel, A., Casali, L. and Hollanders, H. (2015), "How European public sector agencies innovate: the use of bottom-up, policy-dependent and knowledge-scanning innovation methods", Research Policy, Vol. 44 No. 7, pp. 1271-1282.

Audretsch, D.B. and Fritsch, M. (2002), "Growth regimes over time and space", Regional Studies, Vol. 36 No. 2, pp. 113-124.

Audretsch, D.B., Falck, O., Heblich, S. and Lederer, A. (2011), Handbook of Research on Innovation and Entrepreneurship, Edward Elgar Publishing, Willinston.

Audretsch, D.B. (1995), "Firm profitability, growth, and innovation", Review of Industrial Organization, Vol. 10 No. 5, pp. 579-588.

Audretsch, D.B. (2004), "Sustaining innovation and growth: public policy support for entrepreneurshis", Industry and Innovation, Vol. 11 No. 3, pp. 167-191.

Autio, E., Sapienza, H.J. and Almeida, J.G. (2000), "Effects of age at entry, knowledge intensity, and imitability on international growth", Academy of Management Journal, Vol. 43 No. 5, pp. 909-924, doi: 10.2307/1556419.

Banbury, C.M. and Mitchell, W. (1995), "The effect of introducing important incremental innovations on market share and business survival”, Strategic Management Journal, Vol. 16 No. S1, pp. 161-182.

Becker, S. and Ichino, A. (2002), "Estimation of average treatment effects based on propensity scores", Stata Journal, Vol. 2 No. 4, pp. 358-377.

Berger, A.N. and Udell, G.F. (2006), "A more complete conceptual framework for SME finance", Journal of Banking and Finance, Vol. 30 No. 11, pp. 2945-2966.

Berggren, E. and Nacher, T. (2001), "Introducing new products can be hazardous to your company: use the right new-solutions delivery tools", Academy of Management Executive, Vol. 15 No. 3, pp. 92-101.

Birley, S. and Westhead, P. (1990), "Growth and performance contrasts between 'types' of small firms", Strategic Management Journal, Vol. 11 No. 7, pp. 535-557.

Block, J.H., Henkel, J., Schweisfurth, T.G. and Stiegler, A. (2016), "Commercializing user innovations by vertical diversification: the user-manufacturer innovator", Research Policy, Vol. 45 No. 1, pp. 244-259. 
EJIM

24,5

1542

Boyer, T. and Blazy, R. (2014), "Born to be alive? The survival of innovative and non-innovative French micro-start-ups", Small Business Economics, Vol. 42 No. 4, pp. 669-683.

Branzei, O. and Vertinsky, I. (2006), "Strategic pathways to product innovation capabilities in SMEs", Journal of Business Venturing, Vol. 21 No. 1, pp. 75-105.

Brown, J.R., Martinsson, G. and Petersen, B.C. (2012), "Do financing constraints matter for R\&D?", European Economic Review, Vol. 56 No. 8, pp. 1512-1529.

Buddelmeyer, H., Jensen, P.H. and Webster, E. (2010), "Innovation and the determinants of company survival", Oxford Economic Papers, Vol. 62 No. 2, pp. 261-285.

Bugamelli, M., Cannari, L., Lotti, F. and Magri, S. (2012), The Innovation Gap of Italy's Production System: Roots and Possible Solutions, 121, Bank of Italy Occasional Paper, Rome, doi: 10.2139/ ssrn.2064679.

Cader, H.A. and Leatherman, J.C. (2011), "Small business survival and sample selection bias", Small Business Economics, Vol. 37 No. 2, pp. 155-165.

Cavallo, A., Ghezzi, A., Colombelli, A. and Casali, G.L. (2018), "Agglomeration dynamics of innovative start-ups in Italy beyond the industrial district era", International Entrepreneurship and Management Journal, Vols 1-24, doi: 10.1007/s11365-018-0521-8.

Cefis, E. and Ciccarelli, M. (2005), "Profit differentials and innovation", Economics of Innovation and New Technology, Vol. 14 Nos 1-2, pp. 43-61.

Cefis, E. and Marsili, O. (2006), "Survivor: the role of innovation in firms' survival", Research Policy, Vol. 35 No. 5, pp. 626-641.

Chandler, G. and Hanks, S. (1993), "Measuring the performance of emerging businesses: a validation study", Journal of Business Venturing, Vol. 8 No. 5, pp. 391-408.

Clarysse, B., Wright, M. and Van de Velde, E. (2011), "Entrepreneurial origin, technological knowledge, and the growth of spin-off companies", Journal of Management Studies, Vol. 48 No. 6, pp. 1420-1442, doi: 10.1111/j.1467-6486.2010.00991.x.

Cohen, W.M. and Klepper, S. (1996a), "Firm size and the nature of innovation within industries: the case of process and product R\&D", Review of Economics and Statistics, Vol. 78 No. 2, pp. 232-243.

Cohen, W.M. and Klepper, S. (1996b), “A reprise of size and R \& D”, The Economic Journal, Vol. 106 No. 437, pp. 925-951.

Colombelli, A., Krafft, J. and Vivarelli, M. (2016), "To be born is not enough: the key role of innovative start-ups”, Small Business Economics, Vol. 47 No. 2, pp. 277-291.

Colombelli, A. (2016), "The impact of local knowledge bases on the creation of innovative start-ups in Italy”, Small Business Economics, Vol. 47 No. 2, pp. 383-396.

Cozza, C., Malerba, F., Mancusi, M.L., Perani, G. and Vezzulli, A. (2012), "Innovation, profitability and growth in medium and high-tech manufacturing industries: evidence from Italy", Applied Economics, Vol. 44 No. 15, pp. 1963-1976.

Crawford, C.M. (1979), "New product failure rates—facts and fallacies”, Research Management, Vol. 22 No. 5 , pp. 9-13.

Czarnitzki, D. and Delanote, J. (2015), "R\&D policies for young SMEs: input and output effects", Small Business Economics, Vol. 45 No. 3, pp. 465-485.

Damanpour, F. (1991), "Organizational innovation: a meta-analysis of effects of determinants and moderators", Academy of Management Journal, Vol. 34 No. 3, pp. 555-590.

Delmar, F., Davidsson, P. and Gartner, W. (2003), "Arriving at the high-growth firm”, Journal of Business Venturing, Vol. 18 No. 2, pp. 189-216.

Dewangan, V. and Godse, M. (2014), "Towards a holistic enterprise innovation performance measurement system", Technovation, Vol. 34 No. 9, pp. 536-545. 
Dosi, G., Marsili, O., Orsenigo, L. and Salvatore, R. (1995), "Learning, market selection and the evolution of industrial structures”, Small Business Economics, Vol. 7 No. 6, pp. 411-436.

Dziallas, M. and Blind, K. (2019), "Innovation indicators throughout the innovation process: an extensive literature analysis", Technovation, Vol. 80, pp. 3-29.

Eisenhardt, K.M. and Martin, J.A. (2000), "Dynamic capabilities: what are they?", Strategic Management Journal, Vol. 21 Nos 10-11, pp. 1105-1121.

Engel, D., Rothgang, M. and Eckl, V. (2016), "Systemic aspects of R\&D policy subsidies for R\&D collaborations and their effects on private R\&D", Industry and innovation, Vol. 23 No. 2, pp. 206-222.

Finaldi Russo, P., Magri, S. and Rampazzi, C. (2016), "Innovative start-ups in Italy: their special features and the effects of the 2102 law", Politica Economica, Vol. 32 No. 2, pp. 297-330.

Firpo, S., Fortin, N.M. and Lemieux, T. (2009), "Unconditional quantile regressions", Econometrica, Vol. 77 No. 3, pp. 953-973.

Foreman-Peck, J. (2013), "Effectiveness and efficiency of SME innovation policy", Small Business Economics, Vol. 41 No. 1, pp. 55-70.

Forlani, D. and Mullins, J.W. (2000), "Perceived risks and choices in entrepreneurs' new venture decisions", Journal of Business Venturing, Vol. 15 No. 4, pp. 305-322.

Freel, M.S. (2000), "Do small innovating firms outperform non-innovators?”, Small Business Economics, Vol. 14 No. 3, pp. 195-210.

Geroski, P.A. (1999), "Innovation as an engine of competition”, In Competition, Efficiency, and Welfare, Springer, Boston, MA, pp. 13-26.

Geroski, P.A., Machin, S. and Van Reenen, J. (1993), "The Profitability of innovating firms", RAND Journal of Economics, Vol. 24 No. 2, pp. 198-211.

Geroski, P.A., Van Reenen, J. and Walters, C.F. (1997), “How persistently do firms innovate?”, Research Policy, Vol. 26 No. 1, pp. 33-48.

Gilbert, B.A., McDougall, P.P. and Audretsch, D.B. (2006), "New venture growth: a review and extension", Journal of Management, Vol. 32 No. 6, pp. 926-950.

Gupta, P.D., Guha, S. and Krishnaswami, S.S. (2013), "Firm growth and its determinants", Journal of Innovation and Entrepreneurship, Vol. 2 No. 1, p. 15.

Hall, B.H., Lotti, F. and Mairesse, J. (2008), "Employment, innovation, and productivity: evidence from Italian microdata", Industrial and Corporate Change, Vol. 17 No. 4, pp. 813-839.

Helmers, C. and Rogers, M. (2010), "Innovation and the survival of new firms in the UK", Review of Industrial Organization, Vol. 36 No. 3, pp. 227-248.

Heunks, F.J. (1998), "Innovation, creativity and success", Small Business Economics, Vol. 10 No. 3, pp. 263-272.

Holmes, P., Hunt, A. and Stone, I. (2010), “An analysis of new firm survival using a hazard function”, Applied Economics, Vol. 42 No. 2, pp. 185-195.

Howell, J.M., Shea, C.M. and Higgins, C.A. (2005), "Champions of product innovations: defining, developing, and validating a measure of champion behavior", Journal of Business Venturing, Vol. 20 No. 5, pp. 641-661.

Hoy, F., McDougall, P. and D’Souza, D. (1992), "Strategies and environments of high growth firms", in Sexton, D. and Kasarda, J. (Eds), The State of the Art of Entrepreneurship, Kent Publishing, Boston, MA, pp. 341-357.

Hultink, E.J. and Atuahene-Gima, K. (2000), "The effect of sales force adoption on new product selling performance", Journal of Product Innovation Management, Vol. 17 No. 6, pp. 435-450.

Hyytinen, A., Pajarinen, M. and Rouvinen, P. (2015), "Does innovativeness reduce startup survival rates?”, Journal of Business Venturing, Vol. 30 No. 4, pp. 564-581. 
EJIM

24,5

Junkunc, M.T. (2007), "Managing radical innovation: the importance of specialized knowledge in the biotech revolution", Journal of Business Venturing, Vol. 22 No. 3, pp. 388-411.

Knight, F. (1921), Risk, Uncertainty and Profit, Houghton-Mifflin, New York, NY.

Li, H. and Atuahene-Gima, K. (2001), "Product innovation strategy and the performance of new technology ventures in China", Academy of Management Journal, Vol. 44 No. 6, pp. 1123-1134.

Link, A.N. and Bozeman, B. (1991), "Innovative behavior in small-sized firms", Small Business Economics, Vol. 3 No. 3, pp. 179-184.

Love, J.H. and Roper, S. (2015), "SME innovation, exporting and growth: a review of existing evidence", International Small Business Journal, Vol. 33 No. 1, pp. 28-48.

Magliocco, A. and Ricotti, G. (2013), The New Framework for the Taxation of Venture Capital in Italy, Paper No. 167, Bank of Italy Occasional, doi: 10.2139/ssrn.2284785.

McEvily, S.K., Eisenhardt, K.M. and Prescott, J.E. (2004), "The global acquisition, leverage, and protection of technological competencies", Strategic Management Journal, Vol. 25 Nos 8-9, pp. 713-722.

McGee, J.E., Dowling, M.J. and Megginson, W.L. (1995), "Cooperative strategy and new venture performance: the role of business strategy and management experience", Strategic Management Journal, Vol. 16 No. 7, pp. 565-580.

Minetti, R. (2011), "Informed finance and technological conservatism", Review of Finance, Vol. 15 No. 3, pp. 633-692.

Nelson, R.R. and Winter, S.G. (1982), "The Schumpeterian tradeoff revisited", The American Economic Review, Vol. 72 No. 1, pp. 114-132.

Nohria, N. and Gulati, R. (1996), "Is slack good or bad for innovation?", Academy of Management Journal, Vol. 39 No. 5, pp. 1245-1264.

Nooteboom, B. (1994), "Innovation and diffusion in small firms: theory and evidence", Small Business Economics, Vol. 6 No. 5, pp. 327-347.

Oh, D.S., Phillips, F., Park, S. and Lee, E. (2016), "Innovation ecosystems: a critical examination”, Technovation, Vol. 54, pp. 1-6.

Parthasarthy, R. and Hammond, J. (2002), "Product innovation input and outcome: moderating effects of the innovation process", Journal of Engineering and Technology Management, Vol. 19 No. 1, pp. 75-91.

Pérez, J.A.H., Geldes, C., Kunc, M.H. and Flores, A. (2019), "New approach to the innovation process in emerging economies: the manufacturing sector case in Chile and Peru", Technovation, Vol. 79, pp. 35-55.

Porter, M.E. (1980), Competitive Strategy: Techniques for Analyzing Industries and Competitors, The Free Press, New York, NY.

Porter, M.E. (1998), Clusters and the New Economics of Competition, Harvard Business School Press, Boston, MA.

Ram, S. and Jung, H.S. (1991), "Forced' adoption of innovations in organizations: consequences and implications", Journal of Product Innovation Management, Vol. 8 No. 2, pp. 117-126.

Reid, G.C. and Smith, J.A. (2000), "What makes a new business start-up successful?", Small Business Economics, Vol. 14 No. 3, pp. 165-182.

Reid, G.C. (1995), "Early life-cycle behaviour of micro-firms in Scotland", Small Business Economics, Vol. 7 No. 2, pp. 89-95.

Roberts, E.B. (1990), "Evolving toward product and market-orientation: the early years of technologybased firms", Journal of Product Innovation Management, Vol. 7 No. 4, pp. 274-287.

Roberts, P.W. (1999), "Product innovation, product-market competition and persistent profitability in the US pharmaceutical industry", Strategic Management Journal, Vol. 20 No. 7, pp. 655-670. 
Rosenbaum, P.R. and Rubin, D.B. (1983), "The central role of the propensity score in observational studies for causal effects”, Biometrika, Vol. 70 No. 1, pp. 41-55.

Rosenbusch, N., Brinckmann, J. and Bausch, A. (2011), "Is innovation always beneficial? A metaanalysis of the relationship between innovation and performance in SMEs", Journal of Business Venturing, Vol. 26 No. 4, pp. 441-457.

Rubin, D.B. (1997), "Estimating causal effects from large data sets using propensity scores", Annals of Internal Medicine, Vol. 127 No. 8 Part 2, pp. 757-763.

Samuelsson, M. and Davidsson, P. (2009), "Does venture opportunity variation matter? Investigating systematic process differences between innovative and imitative new ventures", Small Business Economics, Vol. 33 No. 2, pp. 229-255.

Santi, C. and Santoleri, P. (2017), "Exploring the link between innovation and growth in Chilean firms", Small Business Economics, Vol. 49 No. 2, pp. 445-467.

Sarkar, M.B., Echambadi, R., Agarwal, R. and Sen, B. (2006), "The effect of the innovative environment on exit of entrepreneurial firms", Strategic Management Journal, Vol. 27 No. 6, pp. 519-539.

Scherer, F.M. and Harhoff, D. (2000), "Technology policy for a world of skew-distributed outcomes", Research Policy, Vol. 29 Nos 4-5, pp. 559-566.

Schumpeter, J.A. (1934), The Theory of Economic Development, Oxford University Press, London.

Senge, P.M. and Carstedt, G. (2001), "Innovating our way to the next industrial revolution", MIT Sloan Management Review, Vol. 42 No. 2, p. 24.

Sethi, R. and Sethi, A. (2009), "Can quality-oriented firms develop innovative new products?", Journal of Product Innovation Management, Vol. 26 No. 2, pp. 206-221.

Shepherd, D. and Wiklund, J. (2009), “Are we comparing apples with apples or apples with oranges? Appropriateness of knowledge accumulation across growth studies", Entrepreneurship: Theory and Practice, Vol. 33 No. 1, pp. 105-123.

Shoham, A. and Fiegenbaum, A. (2002), "Competitive determinants of organizational risk-taking attitude: the role of strategic reference points", Management Decision, Vol. 40 No. 2, pp. 127-141.

Stephan, A. (2014), "Are public research spin-offs more innovative?", Small Business Economics, Vol. 43 No. 2, pp. 353-368.

Teece, D.J., Pisano, G. and Shuen, A. (1997), "Dynamic capabilities and strategic management", Strategic Management Journal, Vol. 18 No. 7, pp. 509-533.

Terziovski, M. (2010), "Innovation practice and its performance implications in small and medium enterprises (SMEs) in the manufacturing sector: a resource-based view", Strategic Management Journal, Vol. 31 No. 8, pp. 892-902.

Thornhill, S. (2006), "Knowledge, innovation and firm performance in high-and low-technology regimes", Journal of Business Venturing, Vol. 21 No. 5, pp. 687-703.

Thurner, T.W., Gershman, M. and Roud, V. (2015), "Partnerships as internationalization strategy: Russian entrepreneurs between local restrictions and global opportunities", Journal of International Entrepreneurship, Vol. 13 No. 2, pp. 118-137.

Vermeulen, P.A., De Jong, J.P. and O'shaughnessy, K.C. (2005), “Identifying key determinants for new product introductions and firm performance in small service firms", The Service Industries Journal, Vol. 25 No. 5, pp. 625-640.

Vossen, R.W. (1998), "Relative strengths and weaknesses of small firms in innovation", International Small Business Journal, Vol. 16 No. 3, pp. 88-94.

Wagner, S. and Cockburn, I. (2010), "Patents and the survival of internet-related IPOs", Research Policy, Vol. 39 No. 2, pp. 214-228.

Weinzimmer, L.G., Nystrom, P.C. and Freeman, S.J. (1999), "Measuring organizational growth: issues, consequences and guidelines", Journal of Management, Vol. 24 No. 2, pp. 235-262. 
Wolff, M.F. (2007), "Forget R\&D spending-think innovation", Research Technology Management, Vol. 50 No. 2, p. 7.

Wright, M., Roper, S., Hart, M. and Carter, S. (2015), "Joining the dots: building the evidence base for SME growth policy”, International Small Business Journal, Vol. 33 No. 1, pp. 3-11.

Zahra, S.A. and George, G. (2002), "Absorptive capacity: a review, reconceptualization, and extension”, Academy of Management Review, Vol. 27 No. 2, pp. 185-203.

Zhang, D., Zhuge, L. and Freeman, R.B. (2020), "Firm dynamics of hi-tech start-ups: does innovation matter?", China Economic Review, Vol. 59, p. 101370.

\section{Corresponding author}

Sergio Longobardi can be contacted at: sergio.longobardi@uniparthenope.it

For instructions on how to order reprints of this article, please visit our website: 